\title{
Intentions to quit upper secondary education among first generation immigrants and native Norwegians: the role of loneliness and peer victimization
}

\author{
Hildegunn Fandrem ${ }^{1}$ (D) $\cdot$ Maren Stabel Tvedt ${ }^{1} \cdot$ Tuomo Virtanen $^{1} \cdot$ Edvin Bru $^{1}$
}

Received: 23 December 2019 / Accepted: 5 February 2021 / Published online: 15 March 2021

(c) The Author(s) 2021

\begin{abstract}
Dropout from upper secondary education is a persistent educational problem, particularly among first-generation immigrant youth. This study examined factors associated with intentions to dropout to gain further insight into the process of leaving upper secondary education. The analyses of 1299 Norwegian first-year upper secondary school students' (88\% native Norwegians, $12 \%$ first-generation immigrants) self-reported intentions to quit school, loneliness, and peer victimization in school showed that first-generation immigrants experienced higher levels of loneliness than native Norwegians. In contrast, there were no differences in the levels of peer victimization and intentions to quit between native Norwegians and first-generation immigrants. However, loneliness showed a significantly stronger association with intentions to quit among first-generation immigrants. The results underscore the importance of tackling first-generation immigrants' loneliness in school to reduce their intentions to quit upper secondary education and thus potentially improve conditions for school completion.
\end{abstract}

Keywords Intentions to quit school - Immigrant status · Poor peer relations · Loneliness · Peer victimization · Upper secondary education

\section{Introduction}

Dropout from upper secondary education represents a major challenge in many Western societies, not only because it is expensive for the community but also because it may hinder further integration and participation in society, and it can have both short- and long-term negative consequences (De Ridder et al., 2012; Freudenberg and Ruglis, 2007; Lamb and Markussen, 2011; Lillejord et al., 2015).

Hildegunn Fandrem

Hildegunn.fandrem@uis.no

1 Norwegian Center for Learning Environment and Behavioural Research in Education,

University of Stavanger, 4026 Stavanger, Norway 
In Norway, all adolescents have a statutory right to be enrolled in an upper secondary educational program, and $98 \%$ proceed directly to such programs from the 10th grade of compulsory school (NOU, 2018: p. 15). However, every fourth student (25.5\%) does not complete upper secondary school after five years, and in line with international trends (e.g., Kilpi Jakonen, 2011; Makarova and Herzog, 2013), we find that first-generation immigrant students are particularly overrepresented (42\% are non-completers after 5 years; Statistics Norway, 2019a, 2019b). It is thus important to gain insights into school factors that might play distinct roles for various groups.

Dropout is rarely a sudden event; rather, it is more frequently an endpoint of a process that begins with disengagement from school and evolves into an intention to quit (Finn, 1989; Frostad et al., 2015; Rumberger and Rotermund, 2012). Makarova and Herzog (2013) found in their qualitative study of immigrants that the relationship with classmates was one of several significant predictors of "hidden school drop-out", i.e., losing interest in the lesson and becoming disengaged during classes. Another qualitative study addressing peer relations and ethnicity in the dropout process also contributes to the understanding of dropout from high school (Grønborg, 2015). The current study focuses on intentions to quit. Previous studies regarding the role of poor peer relations in intentions to quit school are scarce (Carbonaro and Workman, 2013; Frostad et al., 2015; Haugan et al., 2019). No quantitative studies addressing the differences between first-generation immigrants and natives in terms of loneliness and victimization and their relationship with intentions to quit high school were found. Consequently, the main aim of the present study is to investigate whether there are differences between first-generation immigrants and native Norwegians in the associations between the intentions to quit school and two aspects of poor peer relations in school: loneliness and peer victimization. Moreover, differences in levels of intentions to quit, loneliness and peer victimization will be assessed.

\subsection{Intentions to quit and dropping out of upper secondary education among immigrant youth}

Theoretically, intention to quit originates from theories of planned behavior (Ajzen, 2012) and motivational models emphasizing intention as a precursor of actual dropout behavior (Vallerand et al., 1997). Intentions to quit school captures the level of students' inclination to leave school before completion while still enrolled. The concept has been widely used in studies investigating school failure from a motivational perspective (e.g., Alivernini and Lucidi, 2011; Bergeron et al. 2011; Freeny and O'Connell, 2011; Frostad et al., 2015; Hardre and Reeve, 2003; Studsrød and Bru, 2011a; Tvedt et al., 2021; Vallerand et al., 1997). Studies specifically focusing on intentions to quit among immigrant youth are, however, lacking.

Immigrant students may find it difficult to decode the cues used in the classroom and actively engage in the teaching and learning process; accordingly, they may experience both academic and social failure. Furthermore, they may perceive their own cultural practices to be devalued in the school context. Ultimately, the 
enactment of this process is hypothesized to lead to a lack of engagement in school (Bingham and Okagaki, 2018). As no previous studies on differences in the level of intentions to quit between immigrants and natives have been conducted, we need to draw on studies on differences in dropout levels for our study. Across the globe, first-generation immigrants are clearly overrepresented regarding dropout (Kalalahti et al., 2017; Lødding, 2009; Markussen et al., 2006). However, if we look at motivational constructs, a contradictory picture emerges: Minority students reported a higher intensity of learning strategy utilization and stronger mastery and performance motivation (Elstad and Turmo, 2007; Bakken and Hyggen, 2018), more positive attitudes towards school (Chiu et al. 2012) and less academic boredom (Tvedt et al., 2021) than majority students. This contradictory picture makes it relevant to ask whether other factors, such as social relations with peers in school, may play a more important role in intentions to quit among immigrant students.

\subsection{Poor peer relations in school}

\subsubsection{Loneliness in school}

Loneliness can be viewed on a continuum, with students experiencing varying degrees of loneliness (Cassidy and Asher, 1992; Russel et al., 1980). Loneliness may also be viewed as a multidimensional construct, as some researchers (DejongGierveld, 1982; Laine, 1998; Weiss, 1973) have differentiated emotional (lack of intimacy or a close friend) and social (dissatisfaction with friends and lack of a network) loneliness. Furthermore, Laine (1998) introduced the concept of school-based loneliness, which covers both these dimensions but specifies school as the venue. This is in line with the concept of loneliness used by Frostad and his colleagues (2015), which is followed in the current study.

An important backdrop for this study is the assumption that first-generation immigrant youth may be exposed to cultural, social and psychological experiences that, because they are undergoing the acculturation process (Berry, 1997), may affect the significance of positive peer relations in their intentions to quit school. Moreover, migration is a life event that may lead to loss of social relations and create challenges and experiences that may induce feelings of loneliness. Madsen and colleagues (2016) found in their large nationally representative study that 11-, 13- and 15-year-old first-generation immigrant youth in Denmark have a greater risk of loneliness than adolescents with a Danish origin. Similar results have also been found for older adolescents: SoloneminNevo and Sharaga (1997) investigated 15- to 18-year-old youth and found that immigrants experienced more loneliness than their non-immigrant counterparts did. Bakken and Hyggen (2018) studied upper secondary schools in Norway and found that fewer immigrant than native students report that they feel that they fit in with their peers at school. Benner et al. (2017) found overall increased levels of school-related loneliness across the transition to high school in their study of adolescents in the US. However, when US- and foreign-born students were compared, the level of loneliness was similar for the two groups in grade 8 , 
whereas the foreign-born experienced a decline in loneliness and their US-born peers reported a slight increase in loneliness across the transition (ob.cit). This latter finding can be interpreted in line with the immigrant paradox (Sam et al. 2008), suggesting that immigrants often show better adaptation outcomes than their national peers, despite poorer traditional welfare conditions. There is, however, mixed support for this paradox; immigrant students report a weaker sense of belonging in school than their native counterparts (Chiu et al., 2012).

\subsubsection{Peer victimization}

Another critical dimension of poor peer relations in school is exposure to peer victimization, which is documented to have severe negative consequences (Hawker and Boulton, 2000; Holt et al. 2015; Juvenon and Graham, 2001; Sjurs $\varnothing$ et al. 2016, 2019). International studies on victimization, particularly in upper secondary school, are limited. One study indicated that victimization among high school students is characterized more by subtle relational victimization than overt aggression (Storch and Masia-Warner, 2004). The National Public Survey in Norway showed that $2.3 \%$ of students in upper secondary school reported peer victimization in school (Wendelborg, 2017). The lower prevalence of the phenomenon, likely combined with an institutional culture that is focused more on the academic than the social development of students, might be why fewer studies on peer victimization are conducted in upper secondary school than in lower grades.

Findings from the international research focused on primary and lower secondary school are somewhat inconsistent regarding the differences between natives and immigrants in regard to having experienced peer victimization (Fandrem et al., 2009; Hanish and Guerra, 2000; Graham and Juvenon, 2002; Strohmeier and Spiel, 2003). The Health Behavior in School-Aged Children (HBSC) study conducted with nationally representative samples of young people in 26 countries shows, however, that first-generation immigrants are more likely to report bullying victimization than nonimmigrants (Stevens et al., 2019). Based on social identity theory, it may be argued that youth from immigrant families are more likely to be victimized by members of a dominant out-group. This assumption was supported by Sulkowski and colleagues (2014), who showed that immigrants were more often bullied because of race, religion and family income than nonimmigrants. No differences between immigrant and nonimmigrant families were observed regarding victimization because of physical appearance. A few studies conducted in upper secondary schools have shown no differences in peer victimization across immigration status groups for general or ethnic peer victimization (McKenney et al., 2006). However, Slonim-Nevo and Sharaga (1997) found in their study that 15- to 18-year-old immigrant youth experience more problems with peers than their nonimmigrant counterparts. In addition, a study conducted on "alternative" subgroups in upper secondary school showed that members of subgroups (such as "moshers/rockers", "goths", and "emos") generally reported 
more exposure to bullying (Minton, 2012). Thus, being a member of a numerous minority may be a risk factor for being victimized.

\subsubsection{Poor peer relations and intentions to quit school}

Peer relationships both inside and outside school are of increased importance as students become older (Fabes et al., 2009). Thus, positive social relationships in upper secondary school may create powerful incentives for students to come to school. High-quality reciprocal friendships have been found to protect immigrant students from dropping out of school (Grønborg, 2015; Makarova and Herzog, 2013; Peguero and Shaffer, 2015).

Previous research suggests that those who drop out of school feel more isolated (e.g., Reegaard and Rogstad, 2016) and have fewer close relationships (Carbonara and Workman, 2013) than those who complete school. Furthermore, Ricard and Pelletier (2016) found that when academic motivation and parent and teacher support are controlled for (2016), students who drop out of school have fewer reciprocal friendships than completers. Peer relations variables have previously been included in school engagement studies, e.g., students have been asked about feelings of loneliness and the presence of friends in school as part of the school alienation scale (Libbey, 2004). Moreover, Frostad and colleagues (2015) and Haugan and colleagues (2019) found loneliness in school to be strongly positively associated with intentions to quit upper secondary school, but these studies did not investigate the role of immigration status.

To our knowledge, no studies have previously investigated the relationship between peer victimization and intentions to quit or drop out of upper secondary school, whether generally or among immigrants. However, bullying research suggests that emotional distress associated with hostile peer interactions contributes to negative school attitudes and a desire to withdraw from or avoid school (Juvenon et al., 2018). Moreover, Havik et al. (2015) found peer victimization to be an important risk factor for school nonattendance among students in lower secondary school. In addition, examining the association between bullying experiences and teacherrated academic engagement as well as grade point average in middle school, Juvonen et al. (2011) discovered that bullied students were less engaged and had lower academic performance across 3 years of middle school.

There are reasons to believe that positive peer relations in school may play an even more important role in intention to quit school among immigrants than among their native Norwegian counterparts: Immigrants face the process of acculturation (Berry, 1997), which may mean that they have lost friends and have less access to same-ethnicity peers (Bingham and Okagaki, 2018). As generational conflict may be serious in the immigrant group due to differences between adolescents and their parents regarding their affiliation with the culture of origin, peers may be especially important. Tartakovsky (2007) found that perceived social support from friends negatively correlated with acculturative stress and homesickness among immigrant high school students in Israel, while perceived social support from the students' parents did not correlate with the same variables. Considering that emotional stress, which results from the acculturation process, may reduce the capacity to engage in school 
(Berry, 1997), this suggests that a strong focus on peer relationships may function as a buffer for intentions to quit school, especially for first-generation immigrants. Additionally, newly arrived immigrants may have less robust social networks in other arenas, giving school, and the peers there, even greater importance. Moreover, many immigrants come from collectivistically oriented cultures, whereas Norway is a more individualistically oriented culture (Hofstede, 2001). Social relationships are generally less important in individualistic than in collectivistic cultures, and individual achievement is more emphasized. Transferred to the school setting, this also suggests that peer relations in school are important for academic performance among immigrants.

\subsection{The current study}

The main aim of the present study was to investigate potential differences among first-generation immigrant and native Norwegian students in the associations of loneliness and peer victimization with intentions to quit upper secondary school. Differences between first-generation immigrant and native Norwegian students in the levels of intentions to quit school, loneliness and peer victimization were also investigated.

The hypotheses were as follows:

1. First-generation immigrant students will report higher levels of intentions to quit school than native Norwegian students.

2. First-generation immigrant students experience higher levels of loneliness in school than native Norwegian students.

3. First-generation immigrant students will report higher levels of peer victimization than native Norwegian students.

Regarding our main aim, the lack of previous studies meant that we were cautious about posing specific hypotheses. However, based on theoretical assumptions and related research presented above, we expect that loneliness and peer victimization are more strongly associated with intentions to quit among first-generation immigrants than among their native Norwegian counterparts. The following main research question was investigated:

4. Do the associations of loneliness and peer victimization with intentions to quit school differ between first-generation immigrant students and native Norwegian students?

We considered prior academic achievement (GPA), cultural capital (an indicator of socioeconomic status (SES)), study track, and gender as important control variables, as previous research has robustly documented that these factors are important predictors of school dropout or intentions to quit school (Bakken and Hyggen, 2018; Battin-Pearson et al. 2000; Byrhagen et al. 2006; Markussen et al., 2011; Frostad et al., 2015; Frøseth and Sandberg 2011; Lundetræ, 2011; Tvedt et al., 2021). SES and GPA have been found to play essential roles in investigations of the underlying 
reasons why immigrant students are overrepresented as non-completers (Falck et al., 2010; Kilpi-Jakonen, 2011; Lødding, 2009).

\section{Methods}

\subsection{Procedures and sample}

The data in the current study consisted of students' self-reports obtained from an electronic questionnaire and register data from the County Council. First-year students from 82 classes in seven public upper secondary schools in Rogaland County were invited to participate in the study. The schools were purposively selected (Trochim, 2006) to represent a variety of school types (composition of the study programs offered, urban vs. district location, and average GPA requirement for enrolment). In general, completion rates in Rogaland County are slightly higher (78\%) than the national average (75\%), and this holds for first-generation immigrant students (65\% vs. 58\%) (Statistics Norway, 2019a, 2019b, unpublished, received upon inquiry). All seven schools accepted the invitation to participate and facilitated participation for their first-year students. Prior to their consent decision, students received oral and written information about the project, including that participation was voluntary. In addition to the questionnaire that was administered by the students' main teacher in an ordinary school class, register data (GPA from lower secondary school, gender, and study track) were matched to each participating student with an anonymous code. Students were considered able to decide whether to participate or not themselves given their age, their understanding of the clarity of the explained purpose of the study, and the characteristics of the project (e.g., low level of sensitive information). The Norwegian centre for research data (NSD) approved the ethical and privacy procedures applied in the study.

The response rate in the study was $90 \%$, or 1379 participating students. Regarding immigration status, $82.8 \%(n=1142)$ of the students were native Norwegians (one or both parents born in Norway), 5.8\% $(\mathrm{n}=80)$ were second-generation immigrants (both parents, but not the student, born outside Norway), and $11.4 \%(n=157)$ were first-generation immigrants (both parents and student born outside Norway). This proportion of students with an immigrant background (a total of 17\%) is in line with the percentage in the Norwegian youth population (Kale and Hjelde, 2017). Given the scope of this study (comparison of natives and first-generation immigrants), second-generation immigrants were left out. Thus, a total of 1299 students (mean age: 16.5) were included in the analysis: $88 \%$ were native Norwegians (52\% males; $54 \%$ in the vocational track), and $12 \%$ were first-generation immigrants (55\% males; $60 \%$ in the vocational track). Table 1 shows the distribution of the immigrant sample according to the country of origin: Approximately 40\% were from Asian countries and 18\% were from African countries, which indicates that the majority were from collectivistic cultures (Hofstede, 2001). 
Table 1 Origin (birthplace) of the first-generation immigrants in the sample

\begin{tabular}{lll}
\hline Origin & $\mathrm{N}$ & $\%$ \\
\hline $\begin{array}{l}\text { Nordic countries (Sweden, Denmark, } \\
\text { Finland or Iceland) }\end{array}$ & 9 & 5.7 \\
Europe (non-Nordic countries) & 49 & 31.2 \\
North America & 3 & 1.9 \\
South and Central America & 6 & 3.8 \\
Asia & 62 & 39.5 \\
Africa & 28 & 17.8 \\
Australia & - & - \\
Total & 157 & 100 \\
\hline
\end{tabular}

\subsection{Measures}

\subsubsection{Dependent variable}

Intentions to quit school was measured by five items assessing students' serious considerations about dropping out of school, e.g., I often consider quitting school and I really feel that I am wasting my time in school. Four of the statements were drawn from Frostad et al. (2015), whereas one item was added to emphasize explicit behavioral intentions (I have concrete plans to quit school), as in Tvedt et al. (2021). The scoring format was from 1 (Absolutely not true) to 6 (Absolutely true). The Cronbach's $\alpha$ values were 0.89 and 0.87 for native Norwegians and first-generation immigrants, respectively.

\subsubsection{Independent variables}

Loneliness in school was measured by 6 items covering lack of social participation with peers in school, feelings of social isolation and loneliness, e.g., I have no one to spend time with at school and Ifeel lonely in school. This scale was also scored from 1 to 6 (Frostad et al., 2015). The Cronbach's $\alpha$ values were 0.93 and 0.95 for native Norwegians and first-generation immigrants, respectively.

Peer victimization was measured by 4 items reflecting exposure to bullying, e.g., How often have you been bullied/bothered at school by other students in the last school year? The scale has previously been well documented (e.g., Havik et al., 2015; Roland and Idsoe, 2001), even among immigrant students (e.g., Fandrem et al., 2009), and includes victimization by physical assault, teasing, verbal humiliation and social exclusion at school. The scale has a scoring format from 1 to 5 : never (1), seldom (2), 2-3 times per month (3), weekly (4) and daily (5). Prior to responding to the items, students were given a written standard definition of bullying (Roland, 1999). The Cronbach's $\alpha$ values were 0.82 and 0.81 for native Norwegians and first-generation immigrants, respectively.

Immigration status was based on students' report of their country of birth and their mother's and father's countries of birth. Students were coded as first-generation 
immigrants if they themselves were born in a country other than Norway and neither of their parents was born in Norway.

\subsubsection{Control variables}

Prior academic achievement is closely linked to the completion of upper secondary school (Lødding, 2009) and was assessed as the average performance in Norwegian, Mathematics and English (GPA) from the last year of lower secondary school, ranging from 1 (lowest) to 6 (highest).

Cultural capital is regarded as one dimension of SES (Bourdieu, 1993). In Norway, it is found to be the dimension of SES that best predicts academic achievement (Øia, 2011). Number of books at home is considered a valid indicator of cultural capital and was assessed by student self-report, as in the PISA (2012) and Øia (2011). The response format had six intervals for the estimated number of books $(0-10,11-25$, 26-100, 101-200, 201-500, and more than 500).

Dropout from upper secondary school is more prevalent among males (Statistics Norway, 2019a, 2019b). Gender was therefore included as a control variable ( $1=$ male, $2=$ female).

Dropout rates are higher in vocational programs (40\%) than academic programs (13\%) (Statistics Norway, 2019a, 2019b). Study track (vocational=1, academic track $=2$ ) was included as an additional control variable.

School differences across the seven schools were accounted for by introducing $k-1$ (six) dummy variables as controls in the path model.

\subsection{Statistical data analyses}

Statistical analyses were conducted in SPSS (version 25) and in Mplus (version 8.1) in the following steps. First, the distributions, means, standard deviations, and bivariate correlations of the study variables were examined. Second, a series of confirmatory factor analyses were conducted to establish well-fitting baseline models for both groups of interest and examine the factorial invariance of the estimated models across the two groups. To examine the factorial invariance, three models with increased restrictions on the model parameters were estimated. The consecutive models (configural invariance vs. weak factorial invariance and weak invariance vs. strong factorial invariance) were considered invariant if the more restricted model did not fit the data worse than the less restricted model. We followed Chen's (2007) criteria that measurement invariance across the two ethnic groups should be rejected when a $\Delta C F I \geq-0.010$ is supplemented by a $\Delta$ RMSEA $\geq 0.015$. Third, because of the non-normal distribution of the study variables (kurtosis from 2.4 to 18.01 and skewness from 1.7 to 3.7), we conducted Mann-Whitney $U$ tests in addition to t-tests to inspect mean level differences across the two groups in (a) intentions to quit, (b) loneliness, and (c) peer victimization. Fourth, using the Wald test, we tested whether the associations of loneliness and peer victimization with intentions to quit were moderated by the students' ethnic group membership. The multivariate associations between the independent variables and intentions to quit (dependent variable) were examined via structural equation modelling 
Table 2 Correlations, means, and standard deviations of the key study variables

\begin{tabular}{|c|c|c|c|c|c|}
\hline & 1. Intentions to quit & 2. Loneliness & 3. Victimization & 4. Cultural capital & 5. GPA \\
\hline 1 & & $.28^{* * * *}$ & $.22^{* * * *}$ & $-.10^{* *}$ & $-.21^{* * *}$ \\
\hline 2 & $.52 * * *$ & & $.42^{* * *}$ & $.02^{n s}$ & $-.09^{* *}$ \\
\hline 3 & $.31 * * *$ & $.36^{* * *}$ & & $.00^{n s}$ & $-.11^{* * *}$ \\
\hline 4 & $.02^{n s}$ & $-.02^{n s}$ & $.08^{n s}$ & & .39 \\
\hline 5 & $-.26 * *$ & $-.20 *$ & $-.11^{n s}$ & $.18 *$ & \\
\hline$M_{\text {Norwegians }}$ & 1.76 & 1.47 & 1.17 & 3.66 & 3.71 \\
\hline$S D_{\text {Norwegians }}$ & 1.10 & 0.95 & 0.44 & 1.38 & 0.98 \\
\hline$M_{\text {Immigrants }}$ & 1.89 & 1.70 & 1.23 & 2.53 & 2.93 \\
\hline$S D_{\text {Immigrants }}$ & 1.13 & 1.09 & 0.49 & 1.43 & 1.01 \\
\hline
\end{tabular}

$\mathrm{GPA}=$ Grade point average in 10th grade. Correlation coefficients for native Norwegians are presented above the diagonal and those for first-generation immigrant students below the diagonal ${ }^{* * *} p<.001, * * p<.01, * p<.05,{ }^{n s}$ nonsignificant, two-tailed

(SEM), for which the MLR estimator was chosen because of its robustness to non-normal distribution (Muthén and Muthén, 1998-2017).

\section{Results}

Table 2 reports the correlations, means, and standard deviations of the key study variables. In general, the correlations were weak to moderate (Cohen, 1998), with the exception of the strong correlation between perceived loneliness in school and intentions to quit $(r=0.52)$ among immigrant students. As expected, the means for intentions to quit, loneliness and peer victimization were at the lower end of the scale, indicating that most of the students were not seriously considering quitting school, did not feel lonely in school, and were not exposed to bullying.

Table 3 reports the fit indices of the estimated models. All the models showed acceptable fit to the data (Brown and Cudeck, 1993; Kline, 2015). Constraining factor loadings to equality across the ethnic groups did not worsen the model fit, supporting the weak factorial invariance. Furthermore, the decline in model fit caused by making the item intercepts equal across the groups was within the limits proposed by Chen (2007); thus, strong factorial invariance was supported. To summarize, the invariance analyses indicated that the same constructs were measured across immigrants and native Norwegians, enabling subsequent group mean comparisons of intentions to quit, loneliness, and peer victimization in school.

Our hypothesis related to the three initial aims was that immigrant students would report higher levels of intentions to quit, loneliness, and peer victimization in school than native Norwegians. The results of the independent t-tests indicated no significant differences across groups regarding intentions to quit (native Norwegians $\mathrm{M}=1.76, \mathrm{SD}=1.10$, and first-generation immigrant students $M=1.89, S D=1.13$, $t(1297)=-1.36, p=0.18, d=0.12$ ) and peer victimization (native Norwegians $\mathrm{M}=1.17, \mathrm{SD}=0.44$, and first-generation immigrant students $M=1.23, S D=0.49$, 


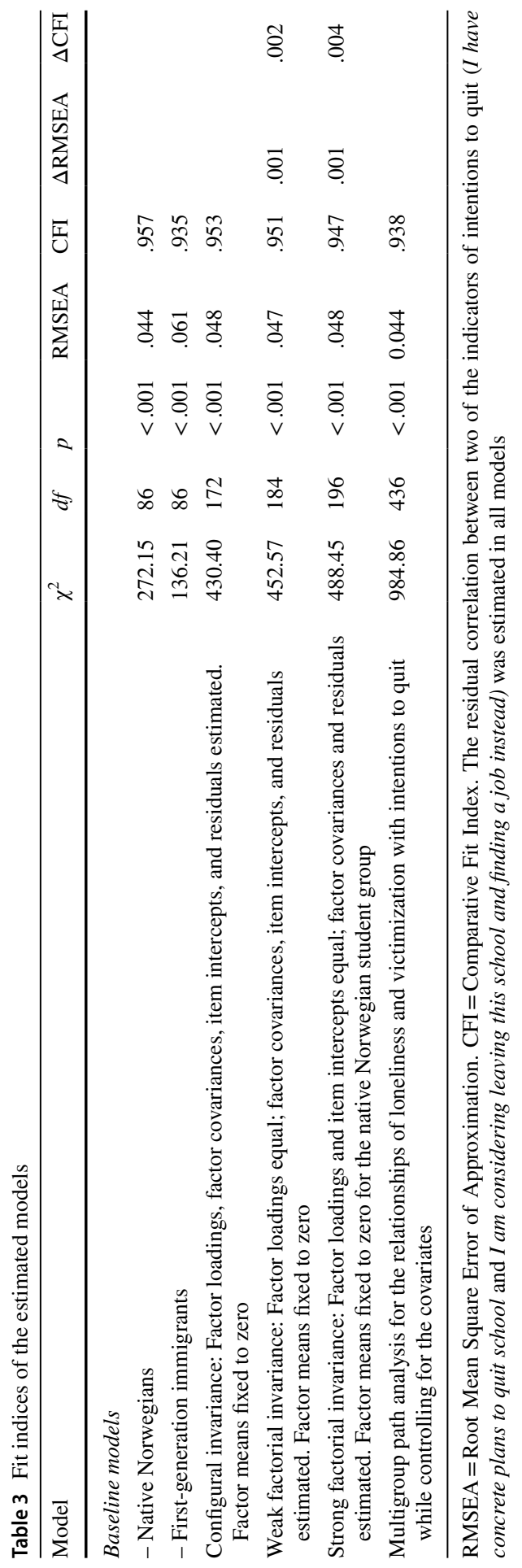


2,50

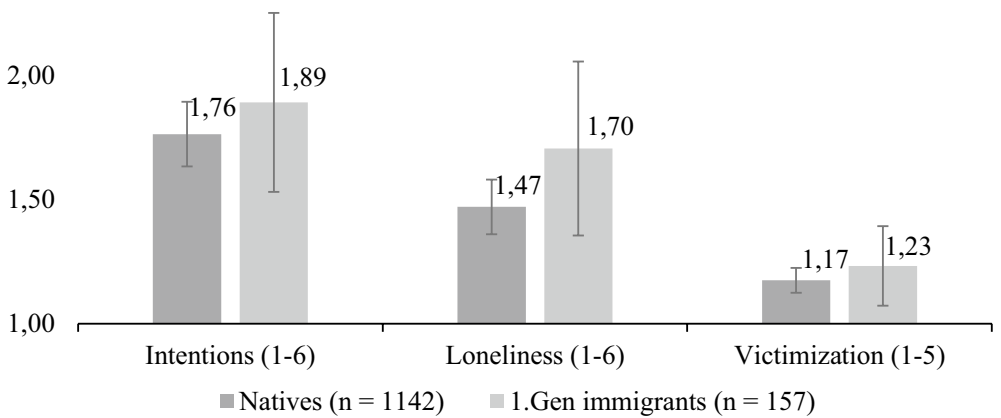

Fig. 1 Means and 95\% CI of means, for native Norwegians and first-generation immigrants for intensions to quit, loneliness and victimization

$t(191)=-1.40, p=0.16, d=0.13)$; thus, these two hypotheses were not supported. However, first-generation immigrants reported significantly more loneliness $(M=1.70$, $S D=1.09)$ than native Norwegians $(M=1.47, S D=0.95), t(190)=-2.57, p=0.01$, $d=0.22$ ), which was in line with the hypothesis. Follow-up analyses were conducted with nonparametric statistics, and the results of the Mann-Whitney U test supported the above reported findings from the t-test (intentions to quit: $U=84,499, p=0.23$, $r=0.03$; victimization: $U=84,376.5, p=0.11, r=0.04$; and loneliness: $U=79,891.5$, $p=0.01, r=0.07)$. To conclude, no significant differences were found between the two groups regarding the levels of intentions to quit and peer victimization, but a significant, small difference (Cohen, 1988) was found in the level of loneliness. The results are visualized in Fig. 1.

The main aim of the current study concerned the potential differences in the strength of the associations of loneliness and peer victimization in school with intentions to quit across the two groups (native Norwegians and first-generation immigrants). The results from the multigroup structural equation model are shown in Table 4. The Wald omnibus test was statistically significant: $\chi^{2}(2)=6.86, p=0.032$. Testing for the equality of individual path coefficients revealed that the association between loneliness and intentions to quit was stronger for first-generation immigrant students $(\mathrm{B}=0.51, p<0.001)$ than native Norwegians $(\mathrm{B}=0.27, p<0.001): \chi^{2}(1)=6.68, p=0.010$. There was no difference between first-generation immigrant students $(\mathrm{B}=0.41, p=0.10)$ and native Norwegians $(\mathrm{B}=0.36, p<0.01)$ with respect to the strength of the association between victimization and intentions to quit: $\chi^{2}(1)=0.295, p=0.587$.

\section{Discussion}

The current study aimed to enlarge the small body of research on the role of peer relationships in native and first-generation immigrant students' intentions to quit upper secondary education. 
Table 4 Unstandardized and Standardized Estimates From the Multigroup Structural Equation Model

\begin{tabular}{|c|c|c|c|c|}
\hline & \multicolumn{4}{|l|}{ Intentions to quit } \\
\hline & \multicolumn{2}{|c|}{ Native Norwegians $(n=1142)$} & \multicolumn{2}{|c|}{$\begin{array}{l}\text { First-generation immigrants } \\
(\mathrm{n}=157)\end{array}$} \\
\hline & $\begin{array}{l}\text { Unstandardized } \\
B\end{array}$ & $\begin{array}{l}\text { Standardized }^{\mathrm{a}} \\
\beta\end{array}$ & $\begin{array}{l}\text { Unstandardized } \\
B\end{array}$ & $\begin{array}{l}\text { Standardized }^{\mathrm{a}} \\
\beta\end{array}$ \\
\hline Loneliness & $.27 * * *$ & $.21 * * *$ & $.51 * * *$ & $.37 * * *$ \\
\hline Peer victimization & $.36 * *$ & $.15^{* *}$ & $.41^{n s}$ & $.16^{n s}$ \\
\hline GPA & $-.26 * * *$ & $-.20 * * *$ & $-.17^{n s}$ & $-.12^{n s}$ \\
\hline Cultural capital & $-.04^{n s}$ & $-.04^{\mathrm{ns}}$ & $.04^{n s}$ & $.04^{n s}$ \\
\hline Study track & $.07^{n s}$ & $.03^{n s}$ & $-.17^{n s}$ & $-.06^{n s}$ \\
\hline Gender & $.16^{n s}$ & $.06^{n s}$ & $.16^{n s}$ & $.06^{n s}$ \\
\hline $\mathrm{R}^{2}$ in model & .15 & & .26 & \\
\hline
\end{tabular}

Study track is coded $1=$ vocational track, $2=$ academic track

Gender is coded $1=$ male, $2=$ female

${ }^{* * *} p<.001, * * p<.01, * p<.05$, ns nonsignificant, two-tailed

${ }^{a}$ Completely standardized beta coefficient (STDYX; both $\mathrm{x}$ and y standardized) are reported for the four continuous IVs, whereas STDY (only y standardized) is reported for the two binary IVs (Muthén and Muthén, 1998-2017, p. 799)

The results show that there were no differences between first-generation immigrants and native Norwegians in intentions to quit and victimization. However, firstgeneration immigrant students reported more loneliness in school than native Norwegian students. Moreover, the association between loneliness and intentions to quit was stronger for first-generation immigrants than for native Norwegians. There was no difference between first-generation immigrant students and native Norwegian students in terms of the strength of the association between peer victimization and intentions to quit.

\subsection{Levels of intentions to quit, loneliness and peer victimization}

The first hypothesis, namely, that first-generation immigrant students would report higher levels of intentions to quit school than native Norwegian students, was not supported. Considering that as many as $42 \%$ of first-generation immigrant students do not complete upper secondary school within 5 years (Statistics Norway, 2019a, $2019 b$ ), the relatively low mean level of intentions to quit among first-generation immigrant students was somewhat surprising. Previous findings show, however, stronger motivation, higher intensity of the use of learning strategies, more positive attitudes toward school and less boredom in the immigrant group (Bakken and Hyggen, 2018; Chiu et al., 2012; Elstad and Turmo, 2007; Tvedt et al., 2021). 
The current finding may thus indicate that these motivation, strategy use, and attitude aspects buffer upper secondary immigrant students' intentions to quit school in the first year, creating a counterweight against the expected difference in intentions to quit between first-generation immigrant and native Norwegian students. Intentions to quit and dropping out may develop later in upper secondary school. Another explanation could be that higher dropout rates among immigrants are linked more to difficulty getting apprenticeships ${ }^{1}$ than to individual intentions to drop out of school. Previous results have shown that only $57.9 \%$ of first-generation immigrants, compared to $74.6 \%$ of native Norwegian students, that apply for apprenticeships received them (Udir, 2019), which represents a structural obstacle in the educational progress.

Our second hypothesis, that first-generation immigrant students would experience higher levels of loneliness in school than native Norwegian students, was supported. This finding aligns with previous research showing a weaker sense of belonging in school among immigrants than among their native counterparts (Bakken and Hyggen, 2018; Chiu et al., 2012). The finding is also in accordance with the acculturation theory of Berry (1997) suggesting that acculturative stress and a more meager social support system are interrelated.

The level of victimization was not found to differ between the two groups; thus, our hypothesis about first-generation immigrant students reporting higher levels of peer victimization was not supported. Our hypothesis was, however, not very strong, as studies that compare immigrant and native students are scarce, and there are inconsistencies in research findings regarding immigrants being more victimized than natives in lower secondary school. One previous Norwegian study among 10th graders showed no differences in victimization between immigrants and native Norwegians (Fandrem et al., 2009). It is possible that the differences found between the two groups in previous international studies relate more to being the minority in school than to having an immigrant background. The lack of difference could also be due to lower levels of victimization in upper secondary school.

\subsection{Associations of loneliness and peer victimization with intentions to quit}

Loneliness showed a stronger association with intentions to quit school among firstgeneration immigrants than among native Norwegians. This supports our expectations that loneliness plays a particular role in first-generation immigrants' intentions to quit upper secondary school. This is in line with our idea that living in Norway but having migrated from a collectivistic culture (Hofstede, 2001) could instigate a stronger need for group belonging than is felt among native Norwegian students. This finding may also reflect that struggling socially more often constitutes an additional stress factor for immigrants, considering that as a group they struggle more

\footnotetext{
1 In Norway, an apprenticeship is a part of vocational upper secondary education, usually 2 years, during which students are trained in a profession through on-the-job training in a company in a practical field.
} 
academically (Field et al., 2007; Lødding, 2009; Markussen et al., 2006; Statistics Norway, 2019a, 2019b).

For victimization, the associations were weaker, and no significant difference was found between the two groups. The reasons for this lack of difference might relate to the fact that the level of victimization is generally lower than the level of loneliness; thus, it is more difficult to reach significant associations regarding this variable. Another explanation may be that peer victimization has serious consequences regardless of whether the target is an immigrant or native student. Moreover, the measurement of loneliness could reflect a more fundamental lack of companionship with peers at school, creating a social situation that with time may become unbearable and trigger school dropout.

Our findings suggest that loneliness could be a serious risk factor for intentions to quit upper secondary school, particularly among first-generation immigrant students. Thus, it is especially important for teachers and schools to implement measures to secure the social inclusion of first-generation immigrants and to identify those who do not seem to fit in with their peers at school at an early stage. One strategy could be to use identity-related perspectives to break down categorizations based on ethnicity and reinforce social categorizations across ethnicity and immigration status (Grønborg, 2015). This includes focusing on building bridges and looking for shared experiences across immigration statuses. Educators must also help immigrant students become accepted members of the classroom community when they cannot rely on a common language to communicate.

To develop successful interventions and prevention strategies, it is important to study the phases prior to actual dropout (Frostad et al., 2015). Our study suggests that, in addition to interventions that promote academic achievement and prevent disengagement in immigrant students, efforts to establish positive peer relations, and especially to prevent loneliness, are important.

\subsection{Limitations and future research}

A limitation of the current study was the relatively small sample size of the immigrant group; a larger sample would have allowed the exploration of other subgroups, e.g., second-generation immigrants, and length of stay, which may be important considering how relevant the acculturative stress explanation is. The use of larger samples for more detailed analyses is recommended for future studies to better capture the heterogeneity within the immigrant youth population. First-generation immigrants were our main group of interest, however, and this subsample was large enough to implement an advanced multigroup approach controlling for GPA, SES and gender. The schools in the current study were strategically selected to represent the diversity of educational institutions and students in the county the students were recruited from. However, the current sample consisted of students from a region in Norway with a slightly higher completion rate among immigrant students compared to the national trend 
(Statistics Norway, 2019a, 2019b, Unpublished, received upon inquiry). This may have deflated the difference between first-generation immigrants and native Norwegians with respect to intentions to quit.

In addition, it is possible that the directions of causality are different from those indicated by the structural model. Intentions to quit could, for example, increase the likelihood of loneliness and victimization. Theory and the differences between immigrants and native Norwegians in terms of the strength of the association of loneliness with intensions to quit argue against this possibility. However, further research should be designed to assess the direction of causality. Regarding the crosssectional design, we specified a model with underlying causal assumptions, but our study design does not allow the plausibility of the demonstrated associations to be tested; this must be done in longitudinal studies. A longitudinal design could model the trajectories of actual dropout behavior and the role of intentions to quit in the dropout process. Further, it would allow the investigation of how different student characteristics (e.g., immigration status) influence such trajectories.

Cross-cultural research on loneliness or loneliness in immigrant children and youth has received little attention from researchers (Kirova, 2001; Neto, 2002). Future studies with larger samples and additional potential predictors of intentions to quit could enrich the complex picture of intentions to dropout and eliminate the potential confounding effects of other variables.

\section{Conclusion}

The current study contributes knowledge on the potential role of social ties between students in dropout prevention efforts. The findings suggest that loneliness is a particular risk factor instigating the dropout process among first-generation immigrants. Moreover, first-generation immigrants seem to be more at risk for loneliness than native Norwegians in upper secondary school. This study makes a unique contribution by being the first quantitative study addressing differences between first-generation immigrants and natives regarding the role of peer relations in intentions to quit upper secondary school.

Completing upper secondary school is crucial for access to further education and permanent employment, and consequently, it is among the first and most important steps that immigrant youth take toward making the most of the opportunities that motivated them and/or their families to migrate (Anisef et al., 2010). Moving from one society to another may contribute to feelings of mistrust and isolation. The results support the notion that measures to improve the social inclusion of immigrants in upper secondary school may increase their chances of completing upper secondary education, which in turn could secure the better integration of immigrants into society. 
Funding Open access funding provided by University Of Stavanger.

\section{Declarations}

Conflict of interest The Authors declare that there is no conflict of interest.

Open Access This article is licensed under a Creative Commons Attribution 4.0 International License, which permits use, sharing, adaptation, distribution and reproduction in any medium or format, as long as you give appropriate credit to the original author(s) and the source, provide a link to the Creative Commons licence, and indicate if changes were made. The images or other third party material in this article are included in the article's Creative Commons licence, unless indicated otherwise in a credit line to the material. If material is not included in the article's Creative Commons licence and your intended use is not permitted by statutory regulation or exceeds the permitted use, you will need to obtain permission directly from the copyright holder. To view a copy of this licence, visit http://creativecommons.org/licen ses/by/4.0/.

\section{References}

Anisef, P., Brown, R. S., Phythian, K., Sweet, R., \& Walters, D. (2010). Early school leaving among immigrants in Toronto secondary schools. Canadian Review of Sociology, 47(2), 103-128. https:// doi.org/10.1111/j.1755-618X.2010.01226.X

Ajzen, I. (2012). The theory of planned behavior. In P. A. M. Lange, A. W. Kruglanski, \& T. E. Higgins (Eds.), Handbook of theories of social psychology, 1 (pp. 438-459). Sage.

Alivernini, F., \& Lucidi, F. (2011). Relationship between social context, self-efficacy, motivation, academic achievement, and intention to drop out of high school: A longitudinal study. The Journal of Educational Research, 104(4), 241-252. https://doi.org/10.1080/00220671003728062

Bakken, A., Hyggen, C. (2018). Trivsel og utdanningsdriv blant minoritetselever $i$ videregående. Hvordan forstå karakterforskjeller mellom elever med ulik innvandrerbakgrunn? [Well-being and educational progress among minority students in upper secondary education. How to understand the differences in grades achieved between students with different immigrant background]. NOVA Rapport 1/18.

Battin-Pearson, S., Newcomb, M. D., Abbott, R. D., Hill, K. G., Catalano, R. F., \& Hawkins, J. D. (2000). Predictors of early high school dropout: A test of five theories. Journal of Educational Psychology, 92(3), 568-582.

Benner, A. D., Boyle, A. E., \& Bakhtiari, F. (2017). Understanding students' transition to high school: Demographic variation and the role of supportive relationship. Journal of Youth Adolescence, 49, 2129-2142. https://doi.org/10.1007/s10964-017-0716-2

Bergeron, J., Chouinard, R., \& Janosz, M. (2011). The impact of teacher-student relationships and achievement motivation on students' intentions to dropout according to socio-economic status. USChina Education Review B, 2, 273-279.

Berry, J. W. (1997). Immigration, acculturation, and adaptation. Applied Psychology, 46, 5-34. https:// doi.org/10.1111/j.1464-0597.1997.tb01087.x

Bingham, G. E., \& Okagaki, L. (2018). Ethnicity and student engagement. In S. L. Christenson, A. L. Reschly, \& C. Wylie (Eds.), Handbook of research student engagement (pp. 65-95). New York: Springer.

Bourdieu, P. (1993). Sociology in question. London: SAGE Publications.

Byrhagen, K. N. Falch, T., Strøm, B. (2006). Frafall I videregående opplaring: Betydningen av grunnskolekarakterer, studieretninger og fylke. [Dropout in upper secondary education: The role of grades from compulsory school, study program, and county]. SØF-RAPPORT NR. 08/06. Trondheim: Senter for $\emptyset$ konomisk forskning AS.

Carbonaro, W., \& Workman, J. (2013). Dropping out of high school: Effects of close and distant friendships. Social science research, 42(5), 1254-1268. https://doi.org/10.1016/j.ssresearch.2013.05.003

Cassidy, J., \& Asher, S. R. (1992). Loneliness and peer relations in young children. Child Development, 63(2), 350-365. https://doi.org/10.1111/j.1467-8624.1992.tb01632.x

Chen, F. F. (2007). Sensitivity of goodness of fit indexes to lack of measurement invariance. Structural equation modeling, 14(3), 464-504. https://doi.org/10.1080/10705510701301834 
Cohen, J. (1988). Statistical power analysis for the behavioral sciences (2nd ed.). Lawrence Erlbaum Associates.

Chiu, M. M., Pong, S.-L., Mori, I., \& Chow, B.W.-Y. (2012). Immigrant students' emotional and cognitive engagement at school: A multilevel analysis of students in 41 countries. Journal of Youth and Adolescence, 41(11), 1409-1425. https://doi.org/10.1007/s10964-012-9763-x

Dejong-Gierveld, J., \& Raadschelders. (1982). Types of loneliness. In L. A. Peplau \& D. Perlman (Eds.), Loneliness. A sourcebook of current theory, research and therapy. Wiley-Interscience.

De Ridder, K. A., Pape, K., Johnsen, R., Westin, S., Holmen, T. L., \& Bjorngaard, J. H. (2012). School dropout: a major public health challenge: a 10-year prospective study on medical and non-medical social insurance benefits in young adulthood, the young-HUNT 1 study (Norway). Journal of Epidemiology and Community Health, 66(11), 995-1000. https://doi.org/10.1136/jech-2011-200047

Elstad, E., \& Turmo, A. (2007). Strategibruk, motivasjon og interesse for naturfag: forskjeller mellom minoritets- og majoritetselever. [Strategy use, motivation and interest in science: Differences between minority and majority students]. Tidsskrift for ungdomsforskning, 7(2), s. 23-44.

Fabes, R. A., Martin, C. L., \& Hanish, L. D. (2009). Children's behaviors and interactions with peers. In K. H. Rubin, W. M. Bukowski, \& B. Laursen (Eds.), Social, emotional, and personality development in context. Handbook of peer interactions, relationships, and groups (pp. 45-62). The Guilford Press.

Falck, T., Borge, L.-E., Lujala, P., Nyhus, O. H. \& Strøm, B. (2010). Årsaker til og konsekvenser av manglende fullføring av videregående opplaring. [Causes and consequences of failure to complete upper secondary education]. SØF-rapport 03/10. Trondheim: Senter for $\varnothing$ konomisk forskning AS. Retrieved from: http://www.sof.ntnu.no/SOF-R\%2003_10.pdf

Fandrem, H., Strohmeier, S., \& Roland, R. (2009). Bullying and victimization among native and immigrant adolescents in Norway: The role of proactive and reactive aggressiveness. The Journal of Early Adolescence, 29(6), 898-923. https://doi.org/10.1177/0272431609332935.

Finn, J. D. (1989). Withdrawing from school. Review of Educational Research, 59(2), 117-142. https:// doi.org/10.3102/00346543059002117

Field, S., Kuczera, M., \& Pont, B. (2007). No more failures. Ten steps to equity in education. OECD.

Freeny, Y., \& O'Connell, M. (2011). The predictors of the intension to leave school among a representative sample of Irish second-level students. British Educational Research Journal, 38(4), 557-574. https://doi.org/10.1080/01411926.2011.563838

Freudenberg, N., \& Ruglis, J. (2007). Reframing school dropout as a public health issue. Preventing Chronic Disease: Public Health Research, Prctice, And Policy, 4(4).

Frostad, P., Pijl, S. J., \& Mjaavatn, P. E. (2015). Losing all interest in school: Social participation as a predictor of the intention to leave upper secondary school early. Scandinavian Journal of Educational Research, 59(1), 110-122. https://doi.org/10.1080/00313831.2014.904420

Graham, S., \& Juvenon, J. (2002). Ethnicity, peer harassment, and adjustment in middle school: An exploratory study. Journal of Early Adolescents, 22(2), 173-199. https://doi.org/10.1177/02724 31602022002003

Grønborg, L. (2015). It's like immigrants stick together, the stupid ones, and the ones who want to learn something: dynamics of peer relations. Social categories, and dropout in vocational educational training. International Journal of Qualitative studies in Education, 28(5), 514-532.

Hardre, P. L., \& Reeve, J. (2003). A motivational model of rural students' intentions to persist in, versus drop out of, high school. Journal of Educational Psychology, 95(2), 347. https://doi.org/10.1037/ 0022-0663.95.2.347

Haugan, J. A., Frostad, P., \& Mjaavatn, P.-E. (2019). A longitudinal study of factors predicting students' intentions to leave upper secondary school in Norway. Social Psychology of Education. https://doi. org/10.1007/s11218-019-09527-0

Havik, T., Bru, E., \& Ertesvåg, S. (2015). School factors associated with school refusal- and truancyrelated reasons for school non-attendance. Social Psychology of Education, 18(2), 221-240. https:// doi.org/10.1007/s11218-015-9293-y

Hawker, D., \& Boulton, M. (2000). Twenty years' research on peer victimization and psychosocial maladjustment: a meta-analytic review of cross-sectional studies. The Journal of Child Psychology and Psychiatry and Allied Disciplines, 41(4), 441-455. https://doi.org/10.1111/1469-7610.00629

Hofstede, G. (2001). Cultures's consequences. Comparing values, behavoiurs, institutions and organizations across nations. Sage Publications Inc. 
Holt, M. K., Vivolo-Kantor, A. M., Polanin, J. R., Holland, K. M., DeGue, S., Matjasko, J. L., Wolfe, M., \& Reid, G. (2015). Bullying and suicidal ideation and behaviors: a meta-analysis. Pediatrics, 135(2), 496-509. https://doi.org/10.1542/peds.2014-1864

Juvenon, J., \& Graham, S. (Eds.). (2001). Peer harassment in school. Guilford Press.

Juvenon, J., Espinoza, G., \& Knifsend, C. (2018). The role of peer relationships in student academic and extracurricular engagement. In S. L. Christenson, A. L. Reschly, \& C. Wylie (Eds.), Handbook of research on student engagement (pp. 387-401). Springer.

Juvonen, J., Wang, Y., \& Espinoza, G. (2011). Bullying experiences and compromised academic performance across middle school grade. Journal of Early Adolescence, 31(1), 152-173. https://doi.org/ $10.1177 / 0272431610379415$

Kalalahti, M., Varjo, J., \& Jahnukainen, M. (2017). Immigrant origin youth and the indecisiveness of choice for upper secondary education in Finland. Journal of youth studies, 20(9), 1242-1262. https://doi.org/10.1080/13676261.2017.1321108

Kale, E., Hjelde, K. (2017). Mental health challenges of immigrants in Norway, a literature review 200917. NAKMI report 1:17. Retrieved from: https://www.fhi.no/publ/2017/mental-health-challengesof-immigrants-in-norway-a-literature-review-200917/

Kilpi-Jakonen, E. (2011). Continuation to upper secondary education in Finland: Children of immigrants and majority compared. Acta Sociologia, 54(1), 77-106. https://doi.org/10.1177/0001699310 392604

Kline, R. B. (2015). Principles and practice of structural equation modeling (4th ed.). Guilford.

Kirova, A. (2001). Loneliness in immigrant children. Implications for classroom practice. Childhood Education, 77(5), 260-267. https://doi.org/10.1080/00094056.2001.10521648

Laine, K. (1998). Finnish students' attributions of school-based loneliness. Scandinavian Journal of Educational Research, 42(2), 401-413. https://doi.org/10.1080/0031383980420406

Lamb, S., \& Markussen, E. (2011). School dropout and completion: an international perspective. In S. Lamb, E. Markussen, R. Teese, N. Sandberg, \& J. Polesel (Eds.), School dropout and completion. International comparative studies in theory and policy (pp. 1-18). Springer.

Libbey, H. P. (2004). Measuring student relationships to school: Attachment, bonding, connectedness, and engagement. Journal of School Health, 74(7), 274-283. https://doi.org/10.1111/j.1746-1561. 2004.tb08284

Lillejord, S., Halvorsrud, K., Ruud, E., Morgan, K, Freyr, T., Fischer-Griffiths, P., Eikeland, O. J., Hauge, T. E. Homme, A. D., \& Manger, T. (2015). Frafall $i$ videregående opplaring: En systematisk kunnskapsoversikt. [Dropout in upper secondary education: A systematic review]. Oslo: Kunnskapssenter for utdanning, www.kunnskapssenter.no

Lundetræ, K. (2011). Does parental educational level predict drop-out from upper secondary school for 16-to 24-year-olds when basic skills are accounted for? a cross country comparison. Scandinavian Journal of Educational Research, 55(6), 625-637. https://doi.org/10.1080/00313831.2011.555925

Lødding, B. (2009). Sluttere, slitere og sertifiserte. Bortvalg, gjennomføring og kompetanseoppnåelse blant minoritetsspråklige ungdommer $i$ videregående opplaring. [Quitters, strugglers and completers. Dropout, completion and qualification attainment among minority youth in upper secondary education]. RAPPORT 12/2009. Oslo: NIFU.

Madsen, K. R., Damsgaard, M. G., Jervelund, S. S., Christensen, U., Stevens, G. W. J. M., Walsh, S., Koushede, V., Nielsen, L., Due, P., \& Holstein, B. E. (2016). Loneliness, immigration background and self-identified ethnicity: a nationally representative study of adolescents in Denmark. Journal of Ethnic and Migration Studies, 42(12), 1977-1955. https://doi.org/10.1080/1369183X.2015.1137754

Makarova, E., \& Herzog, W. (2013). Hidden school dropout among immigrant students: a cross-sectional study. Intercultural Education, 24(6), 559-572. https://doi.org/10.1080/14675986.2013.867603

Markussen, E., Lødding, B., Sandberg, N., \& Vibe, N. (2006). People are different - what does school do? Rapport 3/2006 NIFU STEP.

Markussen, E., Frøseth, M. W., \& Sandberg, N. (2011). Reaching for the unreachable: identifying factors predicting early school leaving and non-completion in norwegian upper secondary education. Scandinavian Journal of Educational Research, 55(3), 225-253. https://doi.org/10.1080/00313831. 2011.576876

McKenney, K. S., Pepler, D., Craig, W., \& Conolly, J. (2006). Peer victimization and psychological adjustment: The experience of Canadian immigrant youth. Electronic Journal in Educational Psychology, 4(2), 239-264. ISSN: 1696-2095. 
Minton, S. J. (2012). Alterophobic bullying and pro-conformist aggression in a survey of upper secondary school students in Ireland. Journal of Aggression, Conflict and Peace Research, 4(2), 86-95. https://doi.org/10.1108/17596591211208292

Muthén, L. K., Muthén, B. O. (1998-2017). Mplus user's guide eighth edition. Muthén Muthén.

Neto, F. (2002). Loneliness and acculturation among adolescents from immigrant families in Portugal. Journal of Applied Social Psychology, 32(3), 630-647.

NOU 2018:15 (2018). Qualified, prepared and motivated. A knowledge base on the structure and content of upper secondary education. Retrieved from: https://www.regjeringen.no/no/dokumenter/nou2018-15/id2621801/

Peguero, A. A., \& Shaffer, K. A. (2015). Academic self-efficasy, dropping out, and the significance of inequality. Sociological Spectrum, 35(1), 46-64. https://doi.org/10.1080/02732173.2014.978428

Ricard, N. C., \& Pelletier, L. G. (2016). Dropping out of high school: The role of parent and teacher selfdetermination support, reciprocal friendships and academic motivation. Contemporary Educational Psychology, 44, 32-40. https://doi.org/10.1016/j.cedpsych.2015.12.003

Roland, E. (1999). School influences on bullying. Rebell Forlag.

Roland, E., \& Idsoe, T. (2001). Aggression and bullying. Aggressive Behavior, 27(6), 446-462. https:// doi.org/10.1002/ab.1029

Rumberger, R. W., \& Rotermund, S. (2012). The relationship between engagement and high school dropout. In S. L. Christenson, A. L. Reschly, \& C. Wylie (Eds.), Handbook of research on student engagement (pp. 491-513). Springer.

Russel, D., Peplau, L. A., \& Cutrona, C. E. (1980). The revised UCLA loneliness scale: Current and discriminant validity evidence. Journal of Personality and Social Psychology, 39(3), 472-480. https:// doi.org/10.1037/0022-3514.3

Sam, D., Vedder, P., Liebkind, K., Neto, F., \& Virta, E. (2008). Immigration, accculturation and paradox of adaptation in Europe. European Journal of Developmental Psychology, 5(2), 138-158. https:// doi.org/10.1080/17405620701563348

Sjurs $\varnothing$, I. R., Fandrem, H., \& Roland, E. (2016). Emotional problems in in traditional and cyber victimization. Journal of School Violence, 15(1), 114-131. https://doi.org/10.1080/15388220.2014.996718

Sjurs $\varnothing$, I. R., Fandrem, H., \& Roland, E. (2019). «All the time, every day, 24/7» A qualitative perspective of PTSD symptoms in long-term cases of traditional and cyber victimization in Norway and ireland. Internatinal Journal of Bullying Prevention, 2, 139-148. https://doi.org/10.1007/ s42380-019-00024-8

Slonim-Nevo, V., \& Sharaga, Y. (1997). Attitudes and behaviour: A comparison of immigrant and nonimmigrant adolescents in Israel. Child and Adolescent Social Work Journal, 14(4), 251-262. https:// doi.org/10.1023/A:1024542224713

Statistics Norway (2019). Completion of upper secondary education. Retrieved from: https://www.ssb.no/ vgogjen and https://www.ssb.no/statbank/table/11224/tableViewLayout1/

Statistics Norway (2019, unpublished, received upon inquiry). Statistics fulfilment divided in immigrant category nationally and in Rogaland County.

Stevens, G. W. J. M., Boer, M., Titzmann, P. F., Cosma, A., \& Walsh, S. D. (2019). Immigration status and bullying victimization: Associations across national and school context. Journal of Applied Developmental Psychology, 66(2020), 101075. https://doi.org/10.1016/j.appdev.2019.101075

Storch, E. A., \& Masia-Warner, C. (2004). The relationship of peer victimization to social anxiety and loneliness in adolescent females. Journal of Adolescents, 27(3), 351-362. https://doi.org/10.1016/j. adolescence.2004.03.003

Sulkowski, M. L., Bauman, S., Wright, S., Nixon, C., \& Davis, S. (2014). Peer victimization in youth from immigrant and non-immigrant US families. School Psychology International, 35(6), 649-669. https://doi.org/10.1177/0143034314554968

Tartakovsky, E. (2007). A longitudinal study of acculturative stress and homesickness: High school adolescents immigrating from Russia and Ukraiane to Israel without parents. Social Psychiatry Psychiatric Epidemiology, 42, 485-494. https://doi.org/10.1007/s00127-007-0184-1

Trochim, William M. (2006). The research methods knowledge base, (2nd Ed). Retrieved from: http:// www.socialresearchmethods.net/kb/ (version current as of 05.05.2018).

Tvedt, M. S., Bru, E., \& Idsoe, T. (2021). Perceived teacher support and intentions to quit upper secondary school: Direct, and indirect associations via emotional engagement and boredom. Scandinavian Journal of Educational Research. https://doi.org/10.1080/00313831.2019.1659401.

Utdanningsdirektoratet (Udir). (2019). The education mirror. Retrieved from: https://www.udir.no/tallog-forskning/finn-forskning/tema/utdanningsspeilet/laereplass/ 
Vallerand, R. J., Fortier, M. S., \& Guay, F. (1997). Self-determination and persistence in a real-life setting: toward a motivational model of high school dropout. Journal of Personality and Social Psychology, 72(5), 1161-1176. https://doi.org/10.1037/0022-3514.72.5.1161

Vasalampi, K., Kiuru, N., \& Salmela-Aro, K. (2018). The role of a supportive interpersonal environment and education-related goal motivation during the transition beyond upper secondary education. Contemporary Educational Psychology, 55, 110-119. https://doi.org/10.1016/j.cedpsych.2018.09.001

Weiss, R. S. (1973). Loneliness. The experience of emotional and social isolation. MIT Press.

Wendelborg, C. (2017). Mobbing og arbeidsro i skolen. Analyse av Elevunders $\phi$ kelsen 2016/17 [Bullying and work in peace. An analysis of the National student survey 2017/2018]. Trondheim: NTNU, Samfunnsforskning.

Øia, T. (2011). Students in lower secondary school. Motivation, mastery and achievements. NOVA Rapport 9/2011. Oslo: Norsk institutt for forskning om oppvekst, velferd og aldring.

Publisher's Note Springer Nature remains neutral with regard to jurisdictional claims in published maps and institutional affiliations. 